\title{
JENIS - JENIS DIATOM (BACILLARYOPHYCEAE) YANG TERDAPAT PADA KOLAM BEKAS PENAMBANGAN EMASDI NAGARI PAMUATAN KECAMATAN KUPITAN KABUPATEN SIJUNJUNG
}

\author{
Abizar* \\ Pendidikan Biologi STKIP PGRI SUMBAR \\ Jalan Gunung Pangilun, Padang 2500 Telp. 0751-70537310 \\ (Diterima 12 April2015, disetujui 14 Mei 2015)
}

\begin{abstract}
Phytoplankton are plant-based living microorganisms floating in the water and able to photosynthesis. One of the place phytoplankton growth was gold mining in the area there was a hole / concave-large basins excavated mining inundated by water, so that the new area and can be used a variety of organisms living in it. Thus organisms that live on a new area was the pioneer organisms. The species of organisms were capable of being a pioneer in one of the water body phytoplankton. The purpose of this research determined the species of phytoplankton and water chemistry physics factor in Nagari Pamuatan Kecamatan Kupitan Kabupaten Sijunjung.This research did at February - Maret 2016 in the Nagari Pamuatan Kecamatan Kupitan Kabupaten Sijunjung. The type of this research was survey descriptive and technique sampling was directly. There were three stations, the stations determined by purposive sampling. I ${ }^{\text {st }}$ Station was the pool of mined gold that its age about 12 months and II $^{\text {nd }}$ Station was the pool of mined gold that its age about 22 months. Moreover III $^{\text {rd }}$ Station was the pool of mined gold that its age about 54 months. The result were the classis of diatom (Bacillaryophyceae)found in pool Former Gold Mining In Nagari Pamuatan that of the three sampling stations 1 ordo, 4 familia, 6 genus and 8 species.
\end{abstract}

Keyword : Bacillaryophyceae, The pool of mined gold, Species, Pioneer organisms.

\begin{abstract}
ABSTRAK
Fitoplankton merupakan mikroorganisme nabati yang hidup melayang di dalam air, relatif tidak mempunyai daya gerak sehingga keberadaannya dipengaruhi oleh kualitas air, serta mampu berfotosintesis. Tujuan penelitian ini untuk menentukan jenis - jenis diatom (bacillaryophyceae) yang terdapat pada kolam bekas penambangan emas dinagari pamuatan kecamatan kupitankabupaten sijunjung. Penelitian ini dilaksanakan pada bulan februari sampai maret 2016 di Nagari Pamuatan Kecamatan Kupitan Kabupaten Sijunjung. Metode penelitian menggunakan survey deskriptif dan teknik pengambilan sampel secara langsung,

*Penulis korespondensi : Abizar. Prodi Pendidikan Biologi STKIP PGRI Sumatera Barat
\end{abstract}


dimana ditentukan tiga stasiun pengambilan sampel. Pengambilan sampel pada masing-masing stasiun yaitu Stasiun I kolam bekas penambangan yang umurnya sekitar 12 bulan dan Stasiun II kolam bekas penambangan yang umurnya sekitar 22 bulan, sedangkan Stasiun III kolam bekas penambangan umurnya sekitar 54 bulan. Hasil penelitian adalah ditemukan jenis diatom (Bacillaryophyceae) yang ditemukan pada kolam bekas penambanganemas yaitu 1 Ordo, 4 Familia, 6 Genus dan 8 Species.

Kata kunci: Bacillaryophyceae, bekas tambang emas, species, organisme pioneer.

\section{PENDAHULUAN}

Alga (ganggang) merupakan tumbuhan talus yang hidup di perairan, baik air tawar maupun air laut. Jenis-jenis yang hidup bebas di air, terutama yang tubuhnya bersel tunggal dan dapat bergerak aktif merupakan penyusun plankton (Tjitrosoepomo, 2009). Plankton merupakan organisme yang hidup melayang atau mengambang di dalam air (Nontji, 1993). Menurut Djuhanda (1980) menjelaskan plankton dapat dibedakan menjadi dua golongan utama yaitu fitoplankton (plankton nabati) dan zooplankton (plankton hewani). Fitoplankton merupakan mikroorganisme nabati yang hidup melayang di dalam air, relatif tidak mempunyai daya gerak sehingga keberadaannya dipengaruhi oleh kualitas air, serta mampu berfotosintesis (Fachrul, 2007). Presscot (1975) menyatakan, kelompok yang dominan di temukan adalah dari kelompok Diatom (Bacillaryophyceae)Berdasarkan hasil survey di lapangan pada tanggal 7 Juni 2015. Kegiatan masyarakat di Nagari Pamuatan ini pada umumnya penambangan emas. Kegiatan penambangan ini antara lain meliputi kegiatan penggalian, pengerukan dan penyedotan. Penambangan mampu memberikan keuntungan secara ekonomi baik kepada Negara maupun masyarakat. 
Vol. 1, No. 1, 2015 Jenis - Jenis Diatom Yang Terdapat Pada Kolam Bekas Penambangan Emas Penambangan emas ini menggunakan alat berat untuk mencari emas. Apabila emas yang dicari penduduk sudah tidak ada, maka penduduk akan mencari ketempat lain. Tempat penambangan emas sebelumnya akan menjadi kolam bekas penambangan emas.Maka lokasi penambangan emas terdapat lubang/ cekungan-cekungan besar bekas galian penambangan yang digenangi oleh air, sehingga adanya areal baru dan bisa dijadikan tempat hidup berbagai organisme didalamnya. Jadi organisme yang hidup pada areal baru disebut dengan organisme pioner. Jenis-jenis yang mampu menjadi organisme pioner pada badan perairan salah satunya fitoplankton, karena fitoplankton ini merupakan kunci yang kehadiran organisme dalam air, tanpa fitoplankton tidak mungkin terjadi kehidupan dalam air. Fitoplankton merupakan mata rantai pertama dalam persediaan energi bagi kehidupan, temasuk salah satunya dari kelompok Diatom (Bacillaryophyceae).

\section{METODE PENELITIAN}

Penelitian ini telah dilakukan pada bulan Februari - Maret 2016 di Nagari Pamuatan Kecamatan Kupitan Kabupaten Sijunjung. Identifikasi sampel dilakukan di Laboratorium Botani Program Studi Pendidikan Biologi STKIP-PGRI Sumatera Barat.

\section{Alat dan Bahan}

Alat dan bahan yang digunakan untuk penelitian ini adalah net plankton (No.25), thermometer Alkohol, botol sampel $250 \mathrm{ml}$, botol sampel plankton ukuran $25 \mathrm{ml}$, mikroskop listrik binokuler, $\mathrm{pH}$ meter, kaca objek, kaca penutup, pipet tetes, 
labu erlemeyer, kamera digital, ember plastik (10 L), alat tulis, jarum suntik dan biuret. Bahan yang digunakan air, kertas label, selotip dan Formalin $40 \%, \mathrm{MnSO}_{4}$ $\mathrm{KOH} / \mathrm{KI}, \mathrm{H}_{2} \mathrm{SO}_{4}$ pekat, $\mathrm{Na}_{2} \mathrm{~S}_{2} \mathrm{O}_{3} 0,0025 \mathrm{~N}$, Penolptelein (pp) $1 \%, \mathrm{NaOH} 0,02 \mathrm{~N}$ dan Amilum 1\% .

\section{Penentuan Stasiun Penelitian}

Metode yang digunakan dalam penelitian ini adalah metode survey deskriptif. Pengambilan sampel dilakukan secara langsung ke lapangan dengan menentukan tiga stasiun penelitian. Penetapan stasiun dilakukan secara purposive sampling. Pengambilan sampel pada masing-masing stasiun yaitu Stasiun I kolam bekas penambangan yang umurnya sekitar 12 bulan dan Stasiun II kolam bekas penambangan yang umurnya sekitar 22 bulan, sedangkan Stasiun III kolam bekas penambangan umurnya sekitar 54 bulan.

\section{HASIL DAN PEMBAHASAN}

Penelitian yang telah dilakukan tentang Jenis- Jenis Fitoplankton Yang Terdapat Pada Kolam Bekas Penambangan Emas Di Nagari Pamuatan Kecamatan Kupitan Kabupaten Sijunjung dari 3 Stasiun pengambilan sampel ditemukan 1 ordo, 4 familia, 6 genus dan 8 species Diatom (Bacillaryophyceae). Pada Stasiun I ditemukan 6 species, Stasiun II ditemukan 2 species dan Stasiun III ditemukan 1species. Hal ini menunujukan bahwa organisme fitoplankton berusaha untuk aktif sehingga terjadi kompetisi antar species fitoplankton, dimana species 
Vol. 1, No. 1, 2015 Jenis - Jenis Diatom Yang Terdapat Pada Kolam Bekas Penambangan Emas

yang unggul dapat bertahan untuk hidup, maka jumlah species semakin sedikit dan jumlah individu semakin banyak (Maogurran 1991 dalam Haumahu, 2005).

Tabel 1. Jenis-Jenis Diatom (Bacillaryophyceae) Yang Ditemukan Pada Kolam Bekas Penambangan Emas Di Nagari Pamuatan Kecamatan Kupitan Kabupaten Sijunjung.

\begin{tabular}{|c|c|c|c|c|}
\hline \multirow{2}{*}{$\begin{array}{l}\mathbf{N} \\
\mathbf{0}\end{array}$} & \multirow[t]{2}{*}{ Taksa } & \multicolumn{3}{|c|}{ Stasiun } \\
\hline & & I & II & III \\
\hline 1 & Gomphonema parvulum Kutz & $\sqrt{ }$ & - & - \\
\hline 2 & Gyrosigma spenceri Cleve. & - & $\sqrt{ }$ & ( \\
\hline 3 & Navicula notanda Pant. & $\sqrt{ }$ & - & - \\
\hline 4 & Navicula viridula Kutz. & $\sqrt{ }$ & - & - \\
\hline 5 & Nitzschia palea Kutz & $\sqrt{ }$ & - & - \\
\hline 6 & Pinnularia gibba Ehrenb. & - & - & $\sqrt{ }$ \\
\hline 7 & Surirella angusta Kutz. & $\sqrt{ }$ & $\sqrt{ }$ & - \\
\hline 8 & Surirella ovata Kutz. & $\sqrt{ }$ & - & - \\
\hline & Jumlah Species & 6 & 2 & 1 \\
\hline
\end{tabular}

Ket: $(\sqrt{ })=$ Ditemukan, $(-)=$ Tidak Ditemukan.

Tabel 2. Klasifikasi Diatom (Bacillaryophyceae) Yang Ditemukan Pada Kolam Bekas Penambangan Emas Di Nagari Pamuatan Kecamatan Kupitan Kabupaten Sijunjung

\begin{tabular}{cllll}
\hline \multicolumn{1}{c}{ Ordo } & \multicolumn{1}{c}{ Familia } & \multicolumn{1}{c}{ Genus } & \multicolumn{1}{c}{ Species } \\
\hline Pennales & Naviculaceae & Navicula & 1. Navicula notanda Pant. \\
& & 2. Navicula viridula Kuetz. \\
& & Gyrosigma & 3. Gyrosigma spenceri Cleve. \\
& & Pinnularia & 4. Pinnularia gibba Ehre. \\
& Nitszchiaceae & Nitszschia & 5. Nitzschia palea Kuetz. \\
& Gomphonemaceae & Gomphonema & 6. Gomphonema parvulum Kuetz. \\
& Surirelaceae & Surirella & 7. Surirella ovata Kuetz. \\
& & 8. Surirella angusta Kuetz. \\
\hline
\end{tabular}

Tabel 3. Kondisi Faktor Fisika Air Pada Kolam Bekas Penambangan Emas Di Nagari Pamuatan Kecamatan Kupitan Kabupaten Sijunjung

\begin{tabular}{ccccc}
\hline No & Parameter & Stasiun I & Stasiun II & Stasiun III \\
\hline 1 & Suhu $\left({ }^{\circ} \mathrm{C}\right)$ & $29^{\circ} \mathrm{C}$ & $29^{\circ} \mathrm{C}$ & $29^{\circ} \mathrm{C}$ \\
2 & $\mathrm{Ph}$ & 7,4 & 7,4 & 7,4 \\
3 & $\mathrm{DO}(\mathrm{ppm})$ & 12,67 & 9,94 & 14,72 \\
4 & $\mathrm{CO}_{2}(\mathrm{ppm})$ & 4,4 & 8,8 & 5,28 \\
\hline
\end{tabular}

Stasiun I didapatkan jenis-jenis Diatom (Bacillaryophyceae) yang paling banyak dibandingkan Stasiun II dan Stasiun III. Hal ini dikarenakan terjadinya 
musim hujan sehingga air sungai masuk ke Stasiun I jadi jenis-jenis Diatom (Bacillaryophyceae) bertambah. Jenis fitoplankton yang ditemukan pada Stasiun I sebanyak 6 species. Pada Stasiun I kolam yang umurnya 12 bulan setelah dilakukan penambangan. Kolam bekas penambangan ini terletak di tepi sungai dengan suhu $29^{\circ} \mathrm{C}$, pH 7,4, oksigen terlarut 12,67 ppm dan $\mathrm{CO}_{2}$ bebas 4,4 ppm.

Stasiun II kolam yang umurnya 22 bulan setelah penambangan. Kolam bekas penambangan ini terletak di tengah perkebunan dengan suhu $29^{\circ} \mathrm{C}, \mathrm{pH} 7,4$, oksigen terlarut 9,94 ppm dan $\mathrm{CO}_{2}$ bebas $8,8 \mathrm{ppm}$. Jenis fitoplankton yang ditemukan pada Stasiun II sebanyak 2 species.

Stasiun III yaitu kolam yang umurnya 54 bulan tidak sama sekali digunakan oleh penduduk untuk pertambangan. Kolam bekas penambangan ini terletak dekat perkebunan dengan suhu $29^{\circ} \mathrm{C}, \mathrm{pH} 7,4$, oksigen terlarut $14,72 \mathrm{ppm}$ dan $\mathrm{CO}_{2}$ bebas 5,28 ppm. Jenis Diatom (Bacillaryophyceae) yang ditemukan pada Stasiun III sebanyak 1 species.

Jenis-jenis yang mampu menjadi organisme pioner pada badan perairan salah satunya fitoplankton, karena fitoplankton ini merupakan kunci yang kehadiran organisme dalam air, tanpa fitoplankton tidak mungkin terjadi kehidupan dalam air. Fitoplankton merupakan mata rantai pertama dalam persediaan energi bagi kehidupan, temasuk salah satunya dari kelompok Diatom (Bacillaryophyceae).

\section{KESIMPULAN}

Berdasarkan hasil penelitian yang telah dilakukan maka dapat disimpulkan bahwa bahwa jenis diatom (Bacillaryophyceae) yang ditemukan pada kolam 
Vol. 1, No. 1, 2015 Jenis - Jenis Diatom Yang Terdapat Pada Kolam Bekas Penambangan Emas bekas penambanganemas yaitu 1 Ordo, 4 Familia, 6 Genus dan 8 Species. Jumlah classis yang paling banyak ditemukan yaitu family Naviculaceae 4 species, family Surirellacea 2 species, family Nitzchiaceae dan Gomphonematacea masing-masing 1 species. Species Diatom (Bacillaryophyceae) yangpaling banyak ditemukan pada Stasiun I 6 species dan species yang paling sedikit ditemukan pada Stasiun II 2 species dan Stasiun III 1 species. Kualitas fisika kimia air pada Kolam Bekas Penambangan Emas Di Nagari Pamuatan yaitu suhu $29^{\circ} \mathrm{C}, \mathrm{pH} 7,4$, oksigen terlarut 9,94 ppm - 14,72 ppm dan $\mathrm{CO}_{2}$ bebas 4,4 ppm - 5,28 ppm. Faktor fisika kimia air ini berada pada kisaran yang normal, dimana dapat mendukung kehidupan Diatom (Bacillaryophyceae) dalam air.

\section{DAFTAR PUSTAKA}

Djuhanda,Tatang.1980. Kehidupan Dalam Setetes Air dan Beberapa Parasit Pada Manusia. Bandung: ITB.

Fachrul, M. F. 2007. Metode Sampling Biologi. Jakarta: Bumi Aksara.

Haumahu, S. 2005. Distribusi Spasial Fitoplankton di Perairan Teluk Haria Saparu, Maluku Tengah. Ambon: Universitas Pattimura.

Nontji, A. 1993. Laut Nusantara. Djambatan. Jakarta.

Prescott, G. W. 1975. Algae of the Western Great Lake Area $6^{\text {th }}$. Printing W. K. G. Brown Company Publishers. Dubuque Iowa.

Titrosoepomo, G. 2009. Taksonomi Tumbuhan (Schizophyta, Thallophyta, Bryophyta, Pteridophyta). Jakarta: Bhatara Karya Aksara. 